\title{
Mitogenomics and the Phylogeny of Mantis Shrimps (Crustacea: Stomatopoda)
}

\author{
Cassandra Koga * and Greg W. Rouse *(D) \\ Scripps Institution of Oceanography, University of California San Diego, La Jolla, CA 92093-0202, USA \\ * Correspondence: ckoga@ucsd.edu (C.K.); grouse@ucsd.edu (G.W.R.)
}

check for

updates

Citation: Koga, C.; Rouse, G.W. Mitogenomics and the Phylogeny of Mantis Shrimps (Crustacea:

Stomatopoda). Diversity 2021, 13, 647 . https://doi.org/10.3390/d13120647

Academic Editor: Bert W. Hoeksema

Received: 2 September 2021

Accepted: 1 December 2021

Published: 5 December 2021

Publisher's Note: MDPI stays neutral with regard to jurisdictional claims in published maps and institutional affiliations.

Copyright: (c) 2021 by the authors. Licensee MDPI, Basel, Switzerland. This article is an open access article distributed under the terms and conditions of the Creative Commons Attribution (CC BY) license (https:/ / creativecommons.org/licenses/by/ $4.0 /)$.
Abstract: Stomatopoda, commonly known as mantis shrimps, are notable for their enlarged second maxillipeds encompassing the raptorial claw. The form of the claw can be used to divide them into two basic groups: smashers and spearers. Previous phylogenetic studies of Stomatopoda have focused on morphology or a few genes, though there have been whole mitochondrial genomes published for 15 members of Stomatopoda. However, the sampling has been somewhat limited with key taxa not included. Here, nine additional stomatopod mitochondrial genomes were generated and combined with the other available mitogenomes for a phylogenetic analysis. We used the 13 protein coding genes, as well as 12S rRNA, 16S rRNA genes, and included nuclear $18 \mathrm{~S}$ rRNA gene sequences. Different rooting options were used for the analyses: (1) single and multiple outgroups from various eumalocostracan relatives and (2) a stomatopod-only dataset, with Hemisquilla californiensis used to root the topologies, based on the current hypothesis that Hemisquilla is the sister group to the rest of Stomatopoda. The eumalocostracan-rooted analyses all showed H. californiensis nested within Stomatopoda, raising doubts as to previous hypotheses as to its placement. Allowing for the rooting difference, the $H$. californiensis outgroup datasets had the same tree topology as the eumalocostracan outgroup datasets with slight variation at poorly supported nodes. Of the major taxonomic groupings sampled to date, Squilloidea was generally found to be monophyletic while Gonodactyloidea was not. The position of H. californiensis was found inside its superfamily, Gonodactyloidea, and grouped in a weakly supported clade containing Odontodactylus havanensis and Lysiosquillina maculata for the eumalocostracan-rooted datasets. An ancestral state reconstruction was performed on the raptorial claw form and provides support that spearing is the ancestral state for extant Stomatopoda, with smashing evolving subsequently one or more times.

Keywords: mitochondrial genome; molecular phylogeny; gene order

\section{Introduction}

Mantis shrimps (Stomatopoda Latreille, 1817) [1] are marine crustaceans well known for their feeding mechanism and complex eyes. Stomatopods construct or occupy burrows and mainly occur in tropical and subtropical regions [2]. These marine carnivores capture prey by spearing or smashing depending on their distinctive second maxilliped appendages, the raptorial claws [3] (Figure 1). Smashers strike with the heel of the dactyl (calcified tip of the claw shaped like a club) after energy is loaded in a saddle spring mechanism [4]. This allows the claw to strike hard-shelled prey. Spearers are ambush predators with elongated serrated raptorial claws enhanced for soft-bodied prey [5]. In addition to their claws, mantis shrimps are of research interest for their complex visual system due to their compound eyes with around 12-16 photoreceptors, capable of seeing ultraviolet, linear, and circular polarized light [6,7]. Stomatopods have many important roles including used as food, as bioindicators of pollution, and their role as predators in marine ecosystems [8-13]. 

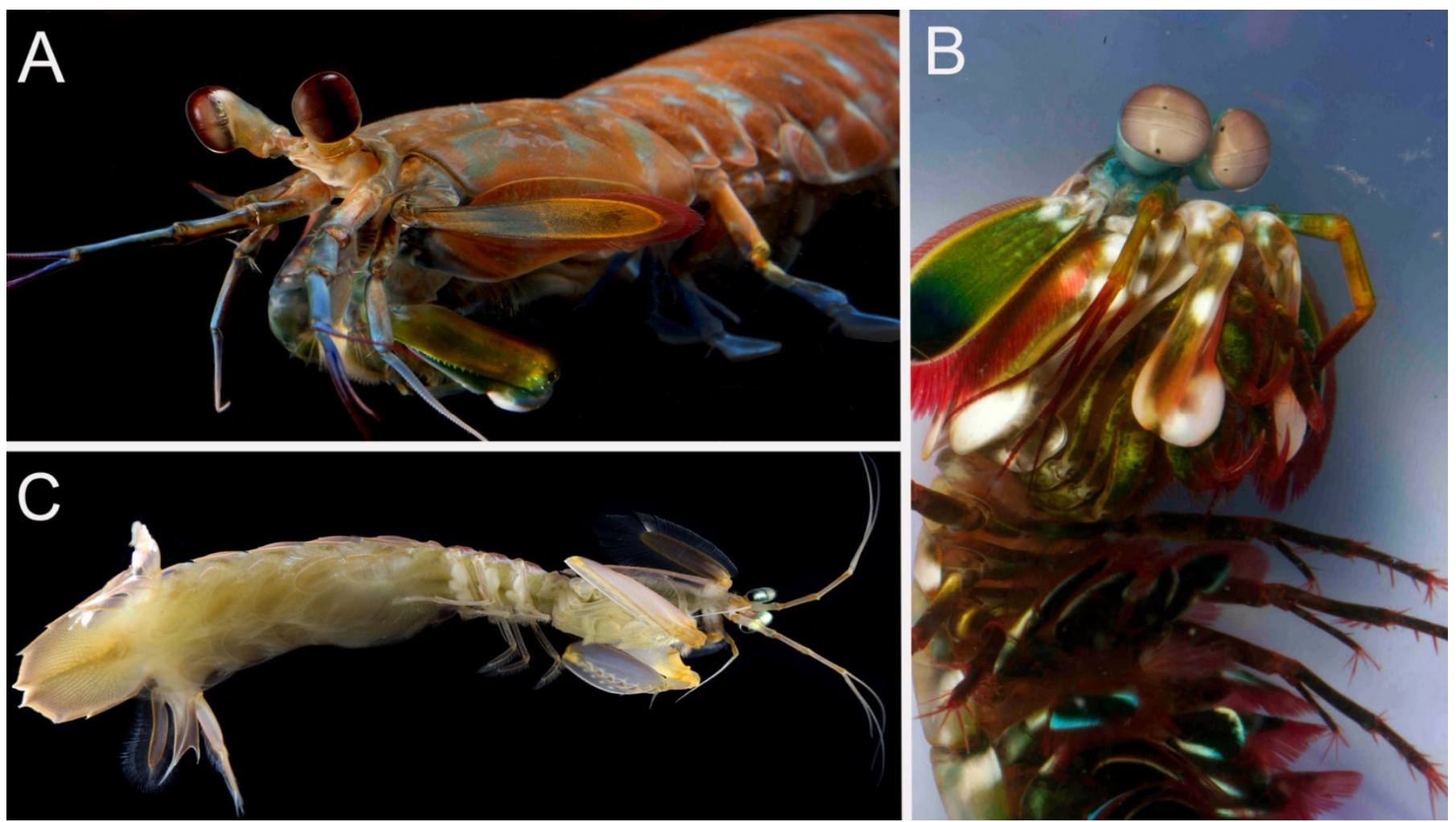
Figure 1. Photographs of Stomatopoda showing the range of raptorial claws. (A) 'Intermediate' claw form: Hemisquilla
californiensis from California. (B) Smasher: Odontodactylus scyllarus from New Guinea (not used in this study). (C) Spearer: Squilla biformis from off Pacific Costa Rica.

Within Stomatopoda, the suborder Unipeltata Latreille, 1825 [14] contains all extant stomatopods, while the other two suborders are for extinct taxa, Palaeostomatopodea and Archaeostomatopodea [15,16]. Unipeltata contains 7 superfamilies, 17 families, and over 100 genera, and nearly 500 accepted species [17,18]: Squilloidea Latreille, 1802 [19]; Gonodactyloidea Giesbrecht, 1910 [20]; Lysiosquilloidea Giesbrecht, 1910 [20]; Bathysquilloidea Manning, 1967 [21]; Eurysquilloidea Manning, 1977 [22]; Erythrosquilloidea Manning \& Bruce, 1984 [23]; and Parasquilloidea Manning, 1995 [24]. Most mantis shrimp species are contained within Squilloidea, Gonodactyloidea, and Lysioquilloidea [25].

One of the more speciose superfamilies, Gonodactyloidea, contains the only four families of smashers out of all the superfamilies, as well as some taxa with spearers. The rest of the stomatopod superfamilies consist only of spearers. Gonodactyloidea has been found to be non-monophyletic in previous molecular studies, owing mainly to the position of the 'intermediate' raptorial claw family, Hemisquillidae Manning, 1980 [26]. Morphological data supports Hemisquillidae as a member of Gonodactyloidea [3,17]; however, previous molecular phylogenetic studies that combined mitochondrial and nuclear genes have recovered it as a sister group to all other superfamilies $[18,25,27]$. Pseudosquillidae Manning, 1977 [22], one of the families of spearers in Gonodactyloidea, also has an unclear position. Some molecular phylogenetic results show Pseudosquillidae to be outside of the rest of the superfamilies, including Gonodactyloidea [25,27], while Van Der Wal et al. [18] showed Pseudosquillidae within Gonodactyloidea. To date, no studies have resolved the potential non-monophyly of Gonodactyloidea regarding the positions of Hemisquillidae and Pseudosquillidae.

Inferring the evolutionary history of smashers and spearers and whether smashers and spearers diverged early $[17,25]$, or whether smashers evolved from a lineage of spearers $[3,28]$ continues to be a topic of study. The results of morphology-based phylogeny by Ahyong and Harling [17] led them to suggest an early divergence of spearing and smashing clades, yet the position of Hemisquillidae and Pseudosquillidae complicates this 
hypothesis. The molecular phylogenies of Ahyong and Jarman [25] and Porter et al. [27] show a single origin of smashing forms, though the positions of Hemisquillidae and Pseudosquillidae suggest spearing may be plesiomorphic for Stomatopoda. The results of the most recent broadscale phylogenetic analysis by Van Der Wal et al. [18] show smashers nested deeply among spearers with a reversal to spearing in Pseudosquillidae. However, they lacked support for key nodes concerning the origin for smashing and spearing nodes in their phylogeny, meaning the evolution of the raptorial claws is still in question [18].

As next-generation sequencing (NGS) technology, such as genome skimming (shallow, low pass sequencing), becomes more accessible, studies using whole mitochondrial genomes in their phylogenies have had better resolution and support compared to those of analyses with partial mitogenomic data [29-32]. To date, 15 complete mitogenomes of Stomatopoda have been published, though phylogenetic studies [33-36] have used only a proportion of these. The study by Yang et al. [36] used the most, with 13 stomatopod mitogenomes and rooted their analysis with Penaeidae Rafinesque, 1815 [37] (Decapoda). They showed a grade of spearing forms relative to a clade of smashers within Gonodactyloidea and overall support values were better than those shown in Van Der Wal et al. [18]. However, more taxon sampling is needed and particularly important is the absence to date of mitogenomic data for Hemisquillidae. Here, we present nine newly sequenced mantis shrimp mitochondrial genomes, including a member of Hemisquillidae. We combine this data with the 15 other available stomatopod mitogenomes and available nuclear 18S rRNA gene data to assess the phylogeny of Stomatopoda and the placement of Hemisquillidae.

\section{Materials and Methods}

\subsection{Sampling}

Samples were collected from the field or from commercial aquarium suppliers (Table 1). Voucher specimens were fixed and preserved in 50\% ethanol and deposited at the Scripps Institution of Oceanography, Benthic Invertebrate Collection, La Jolla, California, USA. Identification was determined by morphology based on the keys of Manning [38] for SIO-BIC C14383 Mesacturoides brevisquamatus Paulson, 1875 [39], and Ahyong [40] for SIOBIC C12730 Gonodactylus sp. and SIO-BIC C12514 Gonodactylellus sp. Mitochondrial COI sequences were also used in assessing the identification of some specimens.

\subsection{DNA Extraction and Sequencing}

DNA was extracted from claws, pleopods, and/or pereiopods using the Zymo QuickDNA Miniprep plus kit, following the manufacturer's protocol. A fragment of the mitochondrial COI gene was amplified using LCO1490(f) and HCO2198(r) primers [41]. Samples were prepared with $8.5 \mu \mathrm{L}$ of water, $12.5 \mu \mathrm{L}$ of Apex 2X Taq RED Master Mix DNA polymerase (Genesee Scientific), $1 \mu \mathrm{L}$ each of forward and reverse primers, and $2.0 \mu \mathrm{L}$ of extracted DNA from specimens. The Eppendorf thermocycler was used to carry out the rest of the PCR with the temperature settings at: $94{ }^{\circ} \mathrm{C} / 3 \mathrm{~min}$.; $\left(94{ }^{\circ} \mathrm{C} / 30 \mathrm{~s}, 47^{\circ} \mathrm{C} / 45 \mathrm{~s}\right.$, $72{ }^{\circ} \mathrm{C} / 1 \mathrm{~min}, 94{ }^{\circ} \mathrm{C} / 30 \mathrm{~s}, 52{ }^{\circ} \mathrm{C} / 45 \mathrm{~s}, 72{ }^{\circ} \mathrm{C} / 1 \mathrm{~min}$ ) x 35 cycles, $72{ }^{\circ} \mathrm{C} / 5 \mathrm{~min}$. Products were purified with $2 \mu \mathrm{L}$ of ExoSAP-IT and run in a thermocycler with the settings: $37^{\circ} \mathrm{C} / 20 \mathrm{~min}$ and $80{ }^{\circ} \mathrm{C} / 15 \mathrm{~min}$. Sanger sequencing was completed by Eurofins Genomics (Louisville, KY, USA). COI sequences obtained from Sanger sequencing for six of the nine taxa studied here are provided in Table 1 with separate accession numbers.

\subsection{Mitochondrial Genome Assembly and Annotation}

Extracted DNA was prepared and sequenced by Novogene (Sacramento, CA, USA) using genome skimming, generating $2 \mathrm{~Gb}$ worth of reads. Data statistics were checked with SeqKit v.0.13.2 [42] and the raw reads were trimmed with Trimmomatic v. 0.39 [43]. The mitochondrial genomes were assembled with Mitofinder v. 1.4 [44] using the Trimmomatic output files. Parameters chosen were Megahit metagenomic assembler v. 1.2.9 [45] and tRNAs were annotated with Arwen v.1.2.3 [46]. The Mitofinder contigs were checked with 
MITOS [47] web server under the mitochondrial code for invertebrates and the annotations were manually edited in Geneious v 11.1.5 [48] if necessary to reflect accurate positions.

Table 1. Collection information, vouchers, GenBank accession numbers (COI, mitogenome, 18S rRNA), and mitogenome length. New COI sequences and mitogenomes are in bold.

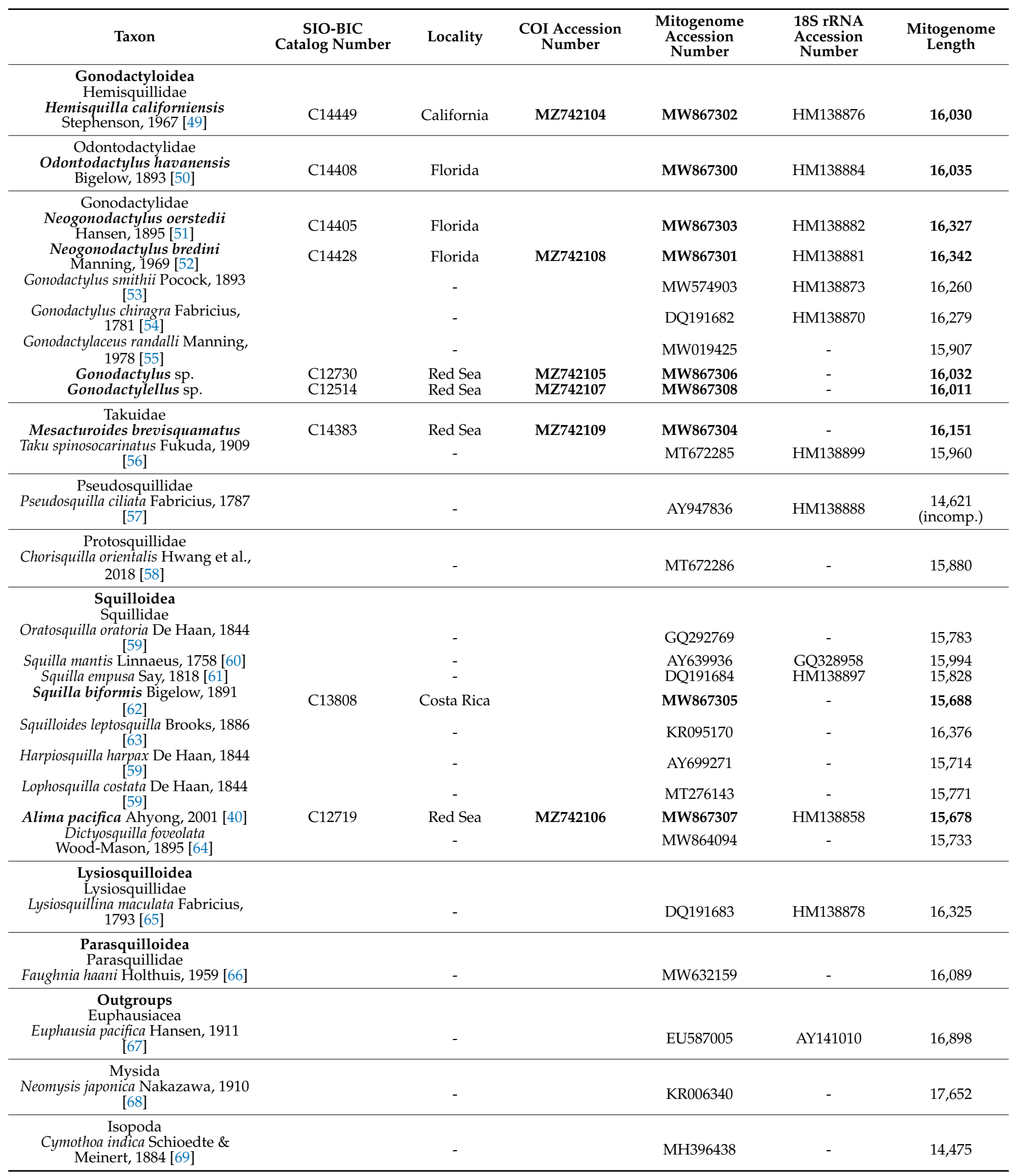




\subsection{Phylogenetic Analyses}

Recent phylogenomic studies of Malacostraca have confirmed Stomatopoda as part of Eumalocostraca. It may either be the sister group to all other Eumalocostraca, or nested within $[70,71]$. Based on these studies, we chose as outgroups three other members of Eumalocostraca with relatively close phylogenetic proximity to Stomatopoda: Euphausia pacifica (Euphausiacea), Cymothoa indica (Isopoda), and Neomysis japonica (Mysida). These were aligned and analyzed with the stomatopod data. Further supplemental analyses were conducted using Euphausia pacifica, Cymothoa indica, and Neomysis japonica as individual outgroups. Stomatopod-only analyses were also performed with Hemisquilla californiensis chosen to root the trees, since previous works $[18,25,27]$ placed Hemisquilla Hansen, 1895 [51] as a sister group to the rest of Stomatopoda. Datasets included the 13 mitochondrial protein coding genes plus the 12S rRNA and 16S rRNA genes, and nuclear 18S rRNA gene. The analyses were conducted with nucleotide-only sequences or as amino acid sequences of the 13 protein coding genes and nucleotide sequences of the 3 rRNA genes: (1) Eumalocostraca outgroups, nucleotide only (EumalNuc); (2) Eumalocostraca outgroups, amino acids and rRNAs (EumalAA); (3) Hemisquilla californiensis outgroup, nucleotide only (HemiNuc); and (4) Hemisquilla californiensis outgroup, amino acids and rRNAs (HemiAA); (5) Euphausia pacifica, Cymothoa indica, and Neomysis japonica as individual outgroups, amino acids, and rRNA genes (Supplementary Materials Figure S1). The 13 protein coding genes were translated to amino acids to mitigate saturation effects from the third codon position. The fraction of parsimony informative characters out of total characters for each dataset is shown in Supplementary Materials Table S1. The NADH6 nucleotide and amino acid data for Chorisquilla orientalis were excluded owing to poor alignment caused by possible contamination. To remove a four base pair insertion, 194 nucleotides were also removed starting at position 941 and on from the cytochrome $b$ gene alignment of Chorisquilla orientalis. Gblocks v. 0.91b [72] was used to remove poorly aligned regions of the 3 rRNA genes with the least stringent settings. Sequences were aligned with MAFFT v. 7.475 [73] under the G-INSI-i method with 1000 iterations, with all three outgroups, each of the three outgroups separately or with members of Stomatopoda only.

Three phylogenetic analyses were performed on each dataset: maximum likelihood (ML), maximum parsimony (MP), and Bayesian inference (BI). The ML analyses were performed in the RaXML v. 2.0.5 [74] interface using RAxML-NG v. 1.0.1 [75]. Gene sequences were concatenated in RAxML-NG and partitioned with variations of the substitution models determined by ModelTest-NG v. 0.1.6 [76] (Supplementary Materials Table S2). The program parameters were set to $\mathrm{ML}+$ thorough bootstrap + consensus with 10 ML searches and 1,000 bootstrap pseudoreplicates for each dataset. Mesquite v. 3.61 [77] was used to concatenate the mixed amino acid and nucleotide datasets for the MP and $\mathrm{BI}$ analyses. For the MP analysis, heuristic searches of concatenated datasets were run in

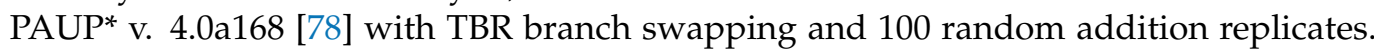
Bootstrap values were gathered via 1000 pseudoreplicates. The BI analysis was conducted in MrBayes v. 3.2.7a [79]. The GTR + I + G model was applied for the nucleotide partitions except for GTR + G for the ND4L and 12S nucleotide partitions in the eumalocostracan outgroup analyses based on the models chosen with ModelTest-NG from the ML analyses. The WAG model was chosen for amino acid partitions in MrBayes. Parameters set for posterior distributions were under the Markov chain Monte Carlo (MCMC) sampling for multiple runs of 20,000,000 generations and 4 chains, with trees sampled every 1000 generations. The first $10 \%$ of the sampled trees were cut away as burn-in after examination of the likelihood scores using Tracer [80].

Approximately Unbiased (AU) tests [81] were performed to assess if one placement of Hemisquilla californiensis was significantly better than another in the phylogenetic results. A constraint tree was made with $H$. californiensis positioned as the sister to a clade of the rest of the stomatopods (as a polytomy), with the eumalocostracan outgroups. The best ML constrained tree topology was generated in RAxML-NG under the same settings as the best unconstrained tree. Whether the best unconstrained tree was significantly better than 
the best constrained tree for the EumalAA and EumalNuc datasets was assessed via the AU test using the default settings in IQ tree v. 1.6.12 [82,83], partitioned as for the original ML analyses. Likelihood-based and most parsimonious ancestral reconstructions of the raptorial claw were mapped onto the Eumalocostrata outgroup EumalAA and EumalNuc ML tree topologies in Mesquite. For the likelihood ancestral state reconstruction, the Mk1 probability model was used. To assess variation in the ancestral state reconstruction owing to alternative tree topologies, 18,000 post-burnin trees from the EumalAA BI analysis were traced under the Mk1 probability model on the EumalAA ML tree topology using the 'Trace Character Over Trees' option in Mesquite. Raptorial claws are classified as spearers or smashers based on the shape of the dactyl. The states are as follows: 0: spearers, 1: smashers, and 2: no claw for the outgroup. Hemisquilla californiensis was scored as $0 / 1$ (assigned either of these states, depending on the transformation used) since it is regarded as an intermediate form $[3,84]$.

\section{Results}

The newly sequenced mitogenomes ranged in total length from 15,678 base pairs (Alima pacifica) to 16,342 base pairs (Neogonodactylus bredini). The usual 13 protein-coding, 2 rRNA and 22 tRNA genes were all present (Figure 2), and the length variation range fell within the range previously found in the complete mitogenomes of other Stomatopoda (Table 1). Most differences can be attributed to variation in the control region. For instance, in Alima pacifica, the control region was found to be 755 base pairs in length while in Neogonodactylus bredini, it was 1,407 base pairs long and this accounted for nearly all the length difference between the mitogenomes. There was otherwise minor variation in the rRNA and tRNA gene lengths. Gene order and direction were conserved among newly sequenced stomatopod genomes and all the available GenBank sequences for stomatopods (Figure 2).

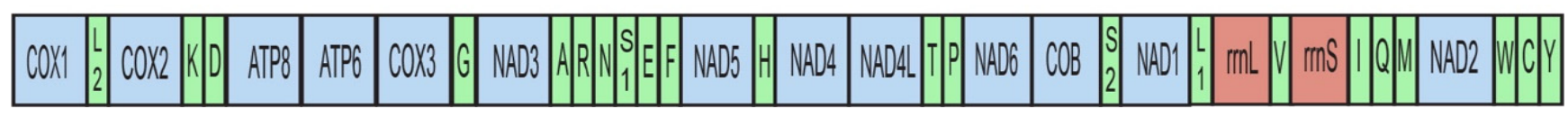

Figure 2. Gene order arrangement of the mitochondrial genome for all stomatopod species used in this study. Blue boxes represent protein coding genes, orange boxes are rRNA genes, and green boxes are tRNA genes. The NAD1, NAD4, NAD4L, NAD5, rrnL, and rrnS genes were in the reverse direction and the rest were in the forward direction.

Figures 3 and 4 show the phylogenetic results produced from the analyses based on the four datasets, two with three outgroup taxa (Figure 3) and two with Stomatopoda only and rooted with Hemisquilla (Figure 4). The nucleotide datasets had similar tree topologies to their respective mixed amino acid and nucleotide datasets, albeit the mixed datasets had lower support than the nucleotide only datasets (Figures 3 and 4). Variations between datasets were due to a few nodes that had low support. The ML and BI trees were congruent in tree topology for the nucleotide only datasets but showed a few differing nodes in the mixed datasets. Incongruence with the ML, BI, and MP analyses occurred at the low supported nodes (Figures 3 and 4). Most differences between trees were from the MP analyses compared to the others. The root position was stable with the three outgroup analyses compared to rooting with individual outgroups (Figures 3 and S1).

There were recurring patterns in all the dataset analyses: Squilloidea was monophyletic and well supported as a spearing clade for three analyses (Figures 3A and 4), with the exception being the ML and BI analyses with the EumalAA dataset (Figures 3B and S1), where it formed a grade. There was high support for a clade of smashers within Gonodactyloidea containing members of Gonodactylidae Giesbrecht, 1910 [20], Protosquillidae Manning, 1980 [26], and Takuidae Manning, 1980 [26]. Gonodactyloidea, however, was non-monophyletic for all analyses (Figures 3, 4 and S1). In the Eumalocostraca-rooted analyses, Lysiosquilloidea and Parasquilloidea terminals nested inside Gonodactyloidea (Figures 3 and S1) and in the Hemisquilla-rooted analyses, Gonodactyloidea was also 
paraphyletic (Figure 4). A clade containing Hemisquilla californiensis, Odontodactylus havanensis, and Lysiosquillina maculata was recovered for all Eumalocostraca outgroup analyses (Figures 3 and S1) and it was grouped with the remaining Gonodactyloidea. In the $H$. californiensis outgroup analyses, the tree topology was essentially the same as those rooted with Eumalocostraca. However, the alternative rooting resulted in $\mathrm{H}$. californiensis, O. havanensis, and L. maculata forming a grade with respect to the rest of Stomatopoda (Figure 4). The nested position of H. californiensis within Stomatopoda, as shown in Figure 3, was tested against the constrained tree with $H$. californiensis as the sister group to Stomatopoda, as in Figure 4, using AU tests. The unconstrained ML tree was significantly better in the EumalNuc dataset $(p=0.0001)$, though for the EumalAA dataset, the two topologies were not significantly different $(p=0.128)$.
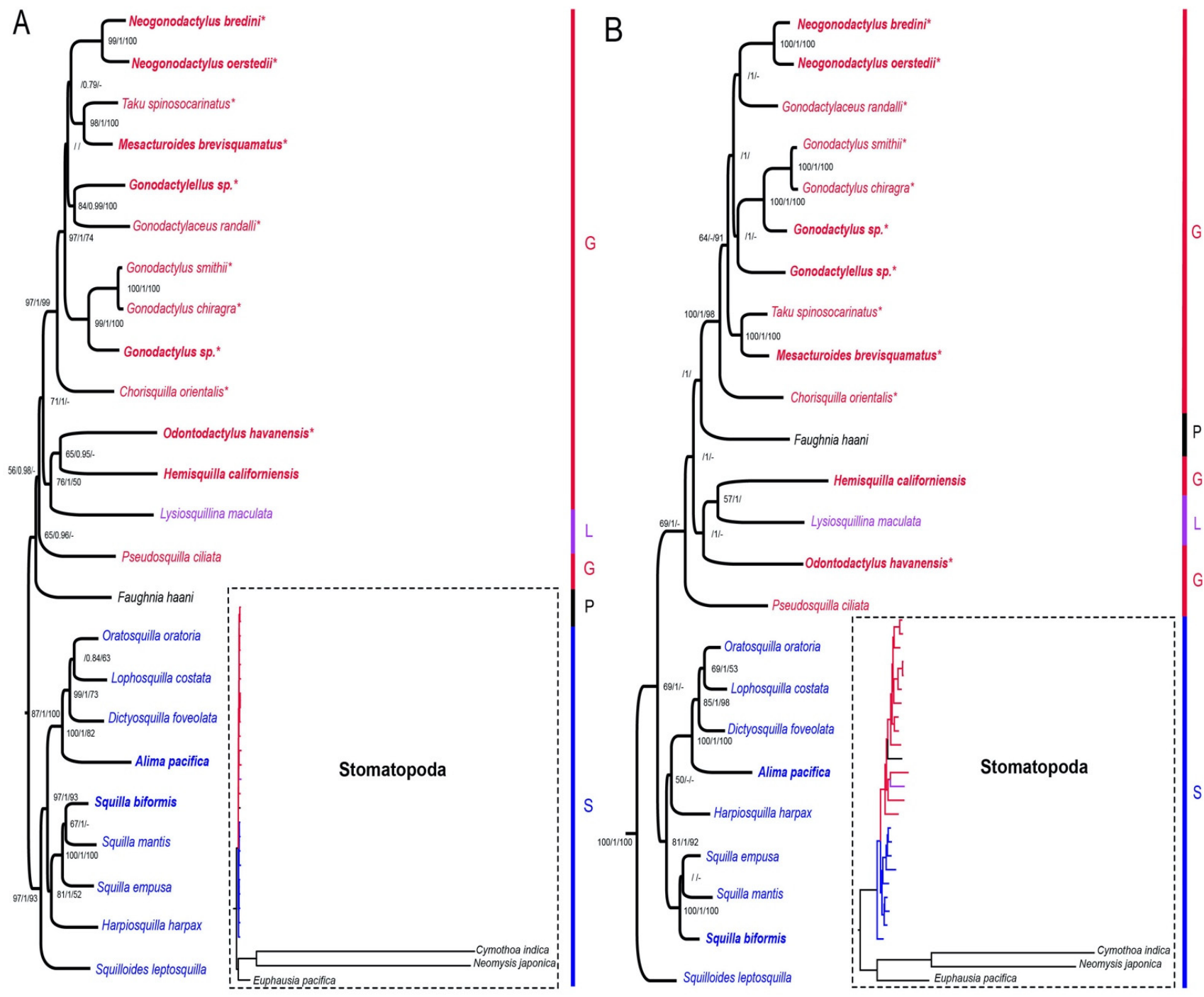

Figure 3. Stomatopoda phylogeny based on the concatenated mitochondrial genes and 18S rRNA sequences; rooted with Euphausia pacifica, Cymothoa indica, and Neomysis japonica (not shown in main figures, they are indicated in the dotted boxes). Newly sequenced taxa are in bold. Each superfamily is coded by the color of the taxon name. Superfamily abbreviations are G: Gonodactyloidea, L: Lysiosquilloidea, S: Squilloidea, P: Parasquilloidea. Asterisks (*) after the taxon name denote smashers. Values at the nodes represent the bootstrap values of ML and MP and the posterior probability of BI in the format (ML/BI/MP). Values not listed were below 50 for bootstrap or below 0.70 for posterior probabilities. Hyphens (-) represent nodes not recovered by the MP or BI analyses. Branch lengths relative to the outgroups are shown in the dotted boxes to the right of each main figure. (A) Maximum likelihood tree from the nucleotide dataset (EumalNuc). (B) Maximum likelihood tree from the mixed amino acid and nucleotide dataset (EumalAA). 


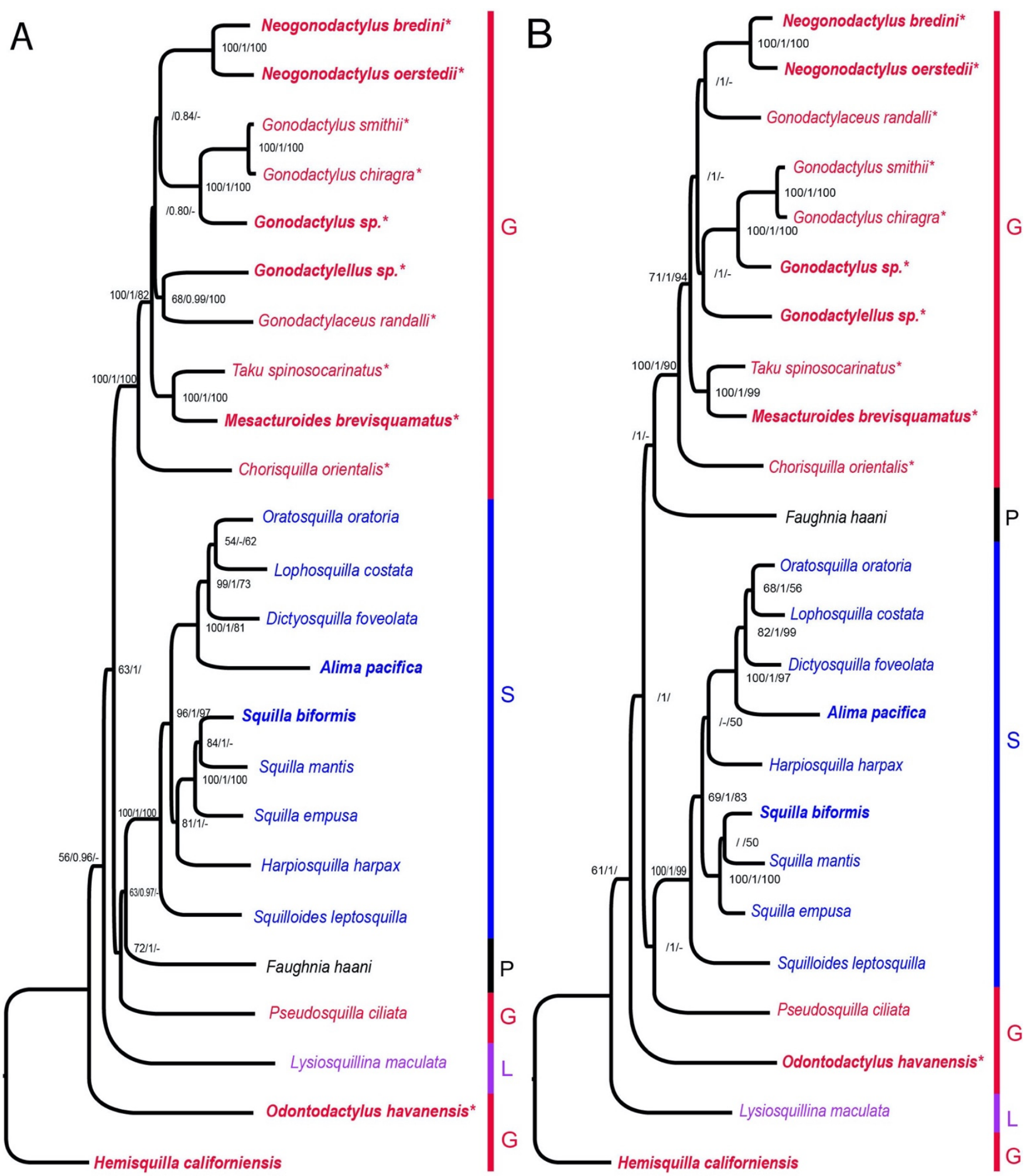

Figure 4. Stomatopoda phylogeny based on the concatenated mitochondrial genes and 18S rRNA sequences; rooted with Hemisquilla californiensis. (A) Maximum likelihood tree from the nucleotide dataset (HemiNuc). (B) Maximum likelihood tree from the mixed amino acid and nucleotide dataset (HemiAA). Newly sequenced species are in bold. Each superfamily is coded by color of the taxon name. Superfamily abbreviations are G: Gonodactyloidea, L: Lysiosquilloidea, S: Squilloidea, P: Parasquilloidea. Asterisks $\left({ }^{*}\right)$ after the taxon name denote smashers. Values at the nodes represent the bootstrap values of ML and MP and the posterior probability of BI in the format (ML/BI/MP). Values not listed were below 50 for bootstrap or below 0.70 for posterior probabilities. Hyphens (-) represent nodes not recovered by the MP or BI analyses. 
The EumalNuc and EumalAA ML tree topologies (Figure 3) were each used for illustrating the ancestral state reconstruction of raptorial claws in Stomatopoda since the tree topologies varied slightly. The Mk1 likelihood ancestral state reconstruction found a proportional likelihood greater that 0.95 for spearers at the ancestral node for Stomatopoda (Figures 5A and 6A). Smashing would appear to have evolved twice at least within Gonodactyloidea. There were three most parsimonious reconstructions (MPRs) for this character in the EumalNuc ML tree, resulting in several scenarios for the raptorial claw evolution, though in all cases spearing was plesiomorphic for Stomatopoda: (1) two origins of smashing, one for O. havanensis and the other for the clade of smashers in Gonodactyloidea, with H. californiensis optimized as a spearer (Figure 5B); (2) one origin of smashing with a reversal to spearing for Lysiosquillina maculata (Figure 5C); and (3) two origins of smashing, one in the clade of Hemisquilla californiensis + Odontodactylus havanensis), and for the clade of smashers in Gonodactyloidea, with H. californiensis optimized as a smasher (Figure 5D). The EumalAA ML tree topology showed a single MPR that essentially matched the scenario in Figure 5B, with two origins of smashing from spearing. One origin was for O. havanensis and the other for the clade of smashers in Gonodactyloidea, with $H$. californiensis optimized as a spearer. Exploration of the effect of suboptimal tree topologies on the ancestral state reconstruction for raptorial claws is summarized in Figure 6C. Here 18,000 post-burnin trees from the EumalAA BI analysis were traced under the Mk1 probability model on the EumalAA ML tree topology (Figure 4A) using the Trace Character Over Trees option in Mesquite. There was some incongruity between the BI analysis and the ML tree, largely in the nodes of Squilloidea (Figure 4A). This is reflected in the summary tree, where two nodes were often absent in the 18,000 post-burnin trees. However, the overall implications for the ancestral state reconstruction of raptorial claws in Stomatopoda were consistent across the 18,000 post-burnin trees (Figure $6 \mathrm{C}$ ). This supports the transformations shown in Figures $5 \mathrm{~A}$ and $6 \mathrm{~A}$ and suggests an ancestral state of spearing for Stomatopoda with one to three transformations to smashing. 


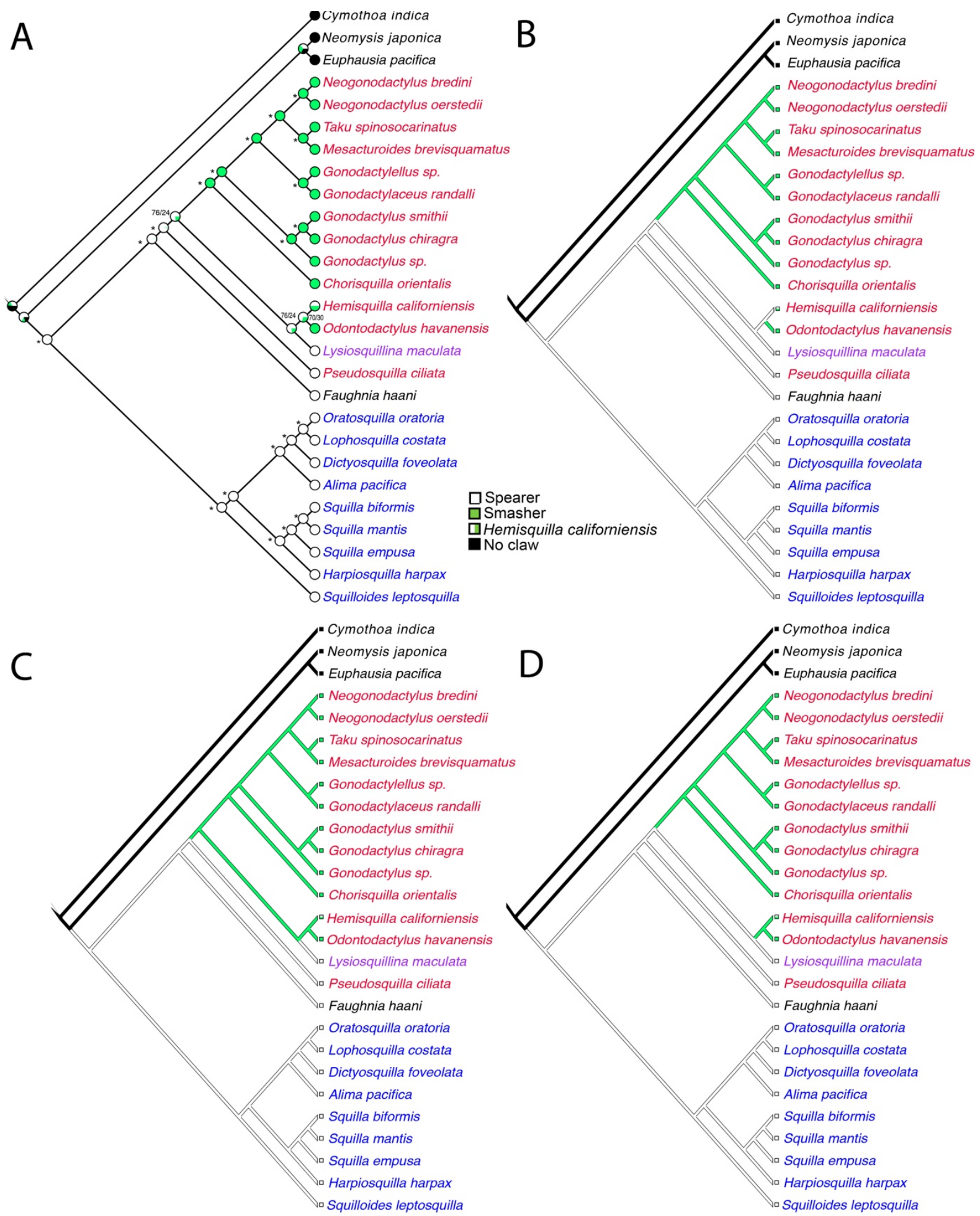

Figure 5. Ancestral state reconstruction, using Mesquite, of the raptorial claws mapped onto the Eumalocostraca outgroup maximum likelihood tree for the EumalNuc dataset. (A) Maximum likelihood reconstruction. Asterisks represent nodes with proportional likelihood estimations of $>95 \%$. Other scores for the ingroup are provided in order of most likely states and separated with a forward slash. (B-D) The three most parsimonious reconstructions. Coloring of terminal names as in Figures 2 and 3. Hemisquilla californiensis was coded as either spearer or smasher. 


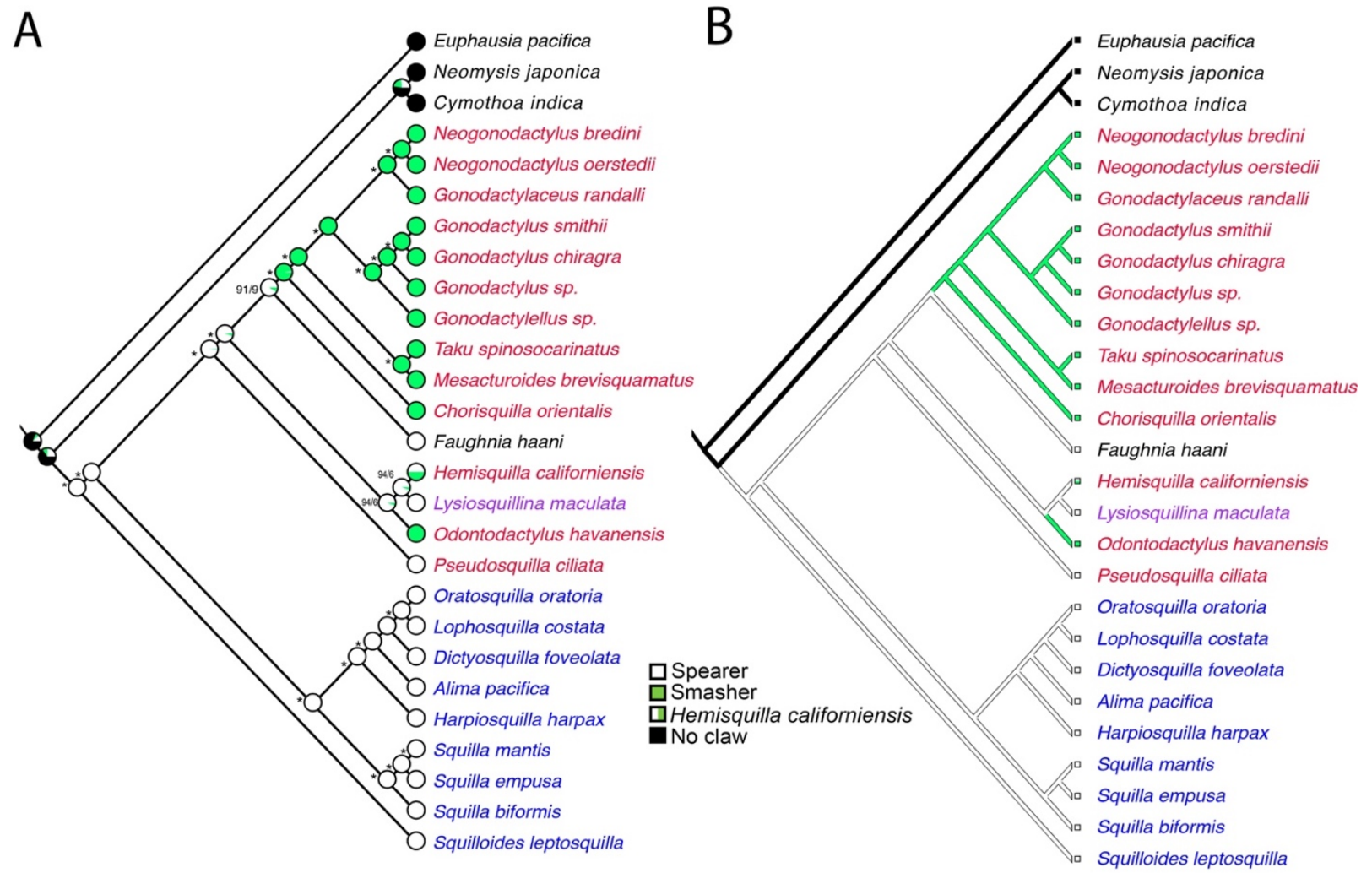

C

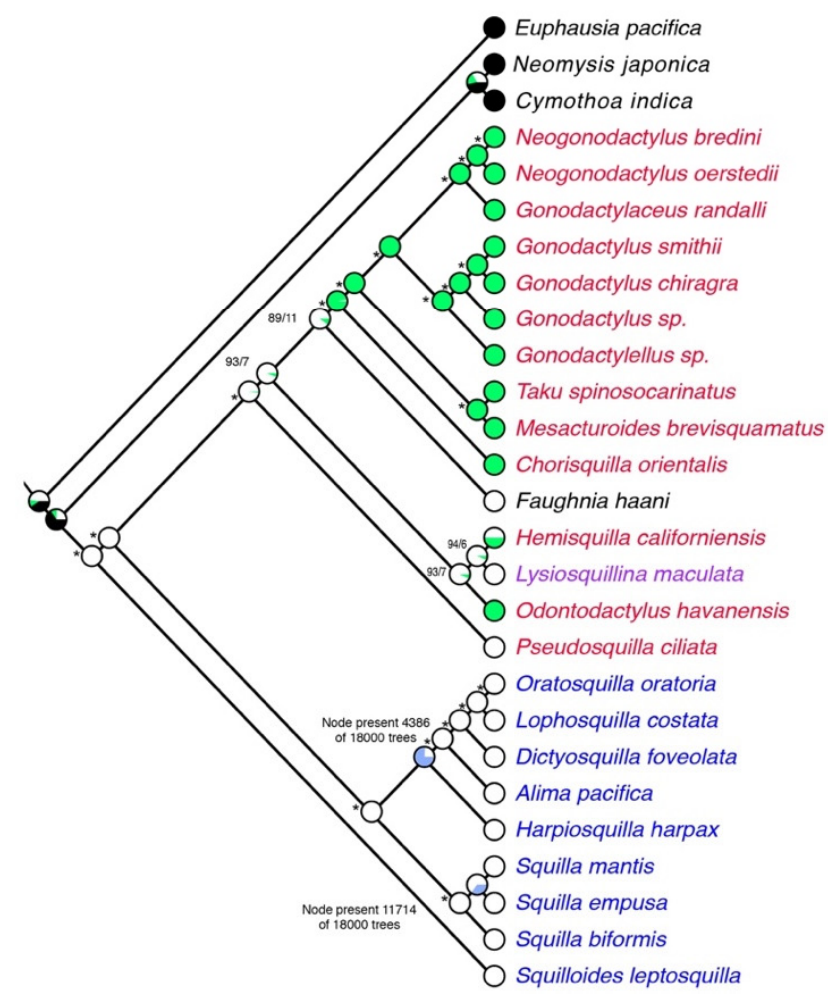

Figure 6. Ancestral state reconstruction, using Mesquite, of the raptorial claws mapped onto the Eumalocostraca outgroup maximum likelihood tree for the EumalAA dataset. (A) Maximum likelihood reconstruction. Asterisks represent nodes with proportional likelihood estimations of $>95 \%$. Other scores for the ingroup are provided in order of most likely states and separated with a forward slash. (B) The single most parsimonious reconstruction for this topology. Coloring of terminal names as in Figures 2 and 3. Hemisquilla californiensis was coded as either spearer or smasher. (C) 'Trace Character Over Trees' summary of ancestral state reconstructions over 18,000 post-burnin trees from the EumalAA BI analysis, traced under the Mk1 probability model on the EumalAA ML tree topology. 


\section{Discussion}

This study provided the first mitogenome phylogenetic analyses of Stomatopoda containing Hemisquilla californiensis, a member of Hemisquillidae, which has been proposed to have an 'intermediate' claw form [3,84]. Furthermore, eight other new stomatopod mitochondrial genomes were also sequenced. Hemisquillidae has been inferred to be the sister group to all other extant stomatopods in recent molecular phylogenetic analyses, and this has led to proposals that its claw form represents the ancestral state [18,27], yet support for this hypothesis appears to be weak (see below). However, all the analyses shown here that were rooted with other Eumalocostraca recovered H. californiensis nested within a paraphyletic Gonodactyloidea (Figures 3 and S1). The results shown in Figure 3 are somewhat like the findings of Barber and Erdmann [85], where Hemisquillidae grouped with Odontodactylidae Manning, 1980 [26], although they only used one mitochondrial gene in that study. The results of our study were significantly better (AU test results) with the EumalNuc dataset (Figure 3A) than the phylogenetic hypotheses of the two most recent comprehensive previous studies [18,27]. However, the EumalAA ML result (Figure 3B) was not significantly better. Additionally, several key nodes in both analyses summarized in Figure 3 showed low support, suggesting that mitochondrial genomes do not have the phylogenetic signal to resolve the overall phylogeny of Stomatopoda.

Other results found here also conflicted with recent molecular phylogenetics analyses of Stomatopoda in other ways. For instance, the Eumalocostraca-rooted ML analyses (Figures 3 and S1) resulted in a near monophyletic Gonodactyloidea, except for Lysiosquillina Manning, 1995 [24] or Lysiosquillina and Faughnia haani. In the EumalNuc analyses, Pseudosquilla Dana, 1852 [86], the only member of Pseudosquillidae in this study, was the sister group to Lysiosquillina plus all the other terminals of Gonodactyloidea (Figure 3A). In the amino acid analyses, it had a similar position, though Faughnia haani (Parasquillidae) also made Gonodactyloidea paraphyletic. These results contrasted with some previous studies [25,27], where Pseudosquillidae was quite distant from the smashing members of Gonodactyloidea. It also differed from the results of Van Der Wal et al. [18], where Pseudosquillidae, a group of spearing stomatopods, was nested within the smashing forms of Gonodactyloidea, implying a reversal from smashing to spearing. In contrast, our results showed a highly supported clade of smashing taxa comprising members of the families Gonodactylidae, Takuidae, and Protosquillidae (Figures 3, 4 and S1). A clade of spearing taxa, Squilloidea, was recovered consistently as well supported in the nucleotide analyses (Figures $3 \mathrm{~A}$ and 4 ), congruent with other studies [18,33-36]. However, the various Eumalocostraca-rooted mixed amino acid nucleotide analyses recovered Squilloidea as a grade (Figures 3B and S1) and the position of Squilloides leptosquilla deserves further investigation.

The previous studies that conflict with the results shown here $[18,25,27]$ were the most comprehensive molecular phylogenetic analyses of Stomatopoda until now, but each relied on only a few mitochondrial genes and the nuclear genes $18 \mathrm{~S}$ rRNA and 28S rRNA, far less data than was used here. The study by Porter et al. [27] showed support values based on approximate likelihood ration tests instead of the bootstrap and posterior probability support values used in other studies on Stomatopoda and in this study. This makes direct comparisons of support difficult. However, the datasets used in Porter et al. [27] and Van der Wal et al. [18] were similar in terms of the genes used and taxon sampling. The values shown by Porter et al. [27] were inferred by those authors to reflect high support, but they contrast markedly with Van der Wal et al. [18], where most major nodes showed very low bootstrap and posterior probability values.

One of the charismatic features of mantis shrimps is the raptorial claws that are used to informally group species into smashers and spearers based on morphology and the way they strike. The evolution and diversification of this raptorial claw form has been a subject of much discussion. Our ancestral state reconstruction of the raptorial claw evolution in Stomatopoda using the Eumalocostraca-rooted datasets (Figures 5 and 6) showed unequivocally that spearing is the ancestral state for extant Stomatopoda. This 
corroborates the views of Caldwell [28] and Ahyong [3] but contrasts markedly with to the findings of Ahyong and Harling [17] and Van Der Wal et al. [18]. The position of Hemisquilla californiensis within Gonodactyloidea (Figures 3 and 5) contradicts theories of a Hemisquilla-like ancestor having an 'intermediate' claw form [18]. Hemisquillidae can strike with either a closed and open dactyl $[25,87]$ and so either spear or smash their prey. The most parsimonious reconstructions of this character transformation allow for some lability in the evolution of smashing and spearing (Figures 5B-D and 6B) and it is not clear what the original state for the ancestor for Hemisquillidae was. Spearing and smashing are more of a continuum and not binary states and deVries et al. [88] and deVries [89] confirm spearers and smashers can eat hard- and soft-bodied prey and have a more generalist diet than thought before.

\section{Conclusions}

This study added nine complete mitochondrial genomes to the 15 available stomatopod mitogenomes, bringing the total to 24 . The new mitogenomes came from the large superfamilies Gonodactyloidea and Squilloidea, and Hemisquilla californiensis, which is in the key taxon Hemisquillidae. The gene order and direction were found to be highly conserved across Stomatopoda and followed the Crustacea ancestral state gene order [90,91]. The new sequences were combined with available mantis shrimp mitogenomes and $18 \mathrm{~S}$ nuclear gene data to allow for further assessment of the phylogeny of Stomatopoda. When non-stomatopod outgroups were used, in combination and singly, Hemisquillidae was found in a relatively derived position instead of being the sister group to all Stomatopoda, as proposed in previous molecular studies. The tree topologies were identical with Stomatopoda-only analyses, which were done here to allow for rooting with Hemisquillidae. The results suggest that the placement of Hemisquillidae as the sister group to Stomatopoda can be seriously questioned. From the outgroup-rooted phylogenies, the ancestral state was inferred to be spearing with several scenarios for the origin or even loss of smashing. Despite showing better support than in previous molecular systematics analysis of Stomatopoda, the results showed several poorly supported nodes. Mitochondrial genomes therefore, do not appear to provide the signal required for the overall phylogeny of Stomatopoda, but will likely be useful for more restricted analyses within the clade.

Supplementary Materials: The following are available online at https:/ /www.mdpi.com/article/10 $.3390 / \mathrm{d} 13120647 / \mathrm{s} 1$, Table S1: Fraction of parsimony informative characters out of the total characters for each gene, Table S2: Models used for each gene in the datasets for maximum likelihood analyses. Figure S1: Maximum likelihood tree topologies from the mixed amino acid and nucleotide dataset analyzed with three different outgroups from Eumalocostraca.

Author Contributions: Conceptualization and resources G.W.R.; formal analysis and data curation, C.K. and G.W.R.; writing-original draft preparation, C.K.; writing-review and editing, C.K. and G.W.R.; supervision, G.W.R. All authors have read and agreed to the published version of the manuscript.

Funding: The collection of Squilla biformis was funded by USA National Science Foundation (NSF) grant number OCE-1634172.

Institutional Review Board Statement: Ethical review and approval were waived for this study, due to Stomatopoda not requiring approval for study.

Informed Consent Statement: Not applicable.

Data Availability Statement: All mitogenomes and Sanger-sequencing data is publicly available on GenBank (www.ncbi.nlm.nih.gov, accessed on 30 November 2021).

Acknowledgments: We thank Mary 'Dewy' White for being the inspiration behind the project. We are also grateful to Phil Zerofski for the collection of Hemisquilla californiensis from California. The specimen of Squilla biformis was collected under a permit issued by the Ministerio de Ambiente y Energía of Costa Rica (Sistema Nacional de Áreas de Conservación/Comisión Nacional para la 
Gestión de la Biodiversidad) for granting a collection permit (SINAC-SE-064-2018). Thanks also to the captain, crew, science party, Alvin team on RV Atlantis AT42-03 for collecting this specimen. The stomatopods from Saudi Arabia were collected thanks to an invitation to GWR by Tim Ravasi and King Abdullah University of Science and Technology. Thank you to Avery Hiley and Marina McCowin for their support in mentoring and preparing DNA extractions. Thank you to Charlotte Seid for cataloging the specimens into SIO-BIC. We also thank the four anonymous reviewers for their helpful and constructive comments.

Conflicts of Interest: The authors declare no conflict of interest.

\section{References}

1. Latreille, P.A. Les Crustacés, Les Arachnides et Les Insectes. In La Regne Animal Distribue d'Apres son Organisation, pour Servir de Base a l'Histoire Naturelle des Animaux et d'Introduction a l'Anatomie Compare; Chez Déterville: Paris, France, 1817; Volume 3, pp. $1-653$.

2. Caldwell, R.L.; Dingle, H. Ecology and evolution of agonistic behavior in stomatopods. Naturwissenschaften 1975, 62, $214-222$. [CrossRef]

3. Ahyong, S.T. Phylogenetic Analysis of the Stomatopoda (Malacostraca). J. Crustacean Biol. 1997, 17, 695-715. [CrossRef]

4. $\quad$ Patek, S.N.; Korff, W.L.; Caldwell, R.L. Deadly strike mechanism of a mantis shrimp. Nature 2004, 428, 819-820. [CrossRef]

5. DeVries, M.S.; Murphy, E.A.K.; Patek, S.N. Strike mechanics of an ambush predator: The spearing mantis shrimp. J. Exp. Biol. 2012, 215, 4374-4384. [CrossRef]

6. Marshall, N.J. A unique colour and polarization vision system in mantis shrimps. Nature 1988, 333, 557-560. [CrossRef]

7. Thoen, H.H.; How, M.J.; Chiou, T.H.; Marshall, J. A Different Form of Color Vision in Mantis Shrimp. Science 2014, 343, 411-413. [CrossRef]

8. Sukumaran, K.K. Study on the fishery and biology of the mantis shrimp Oratosquilla nepa (Latreille) of south Kanara coast during 1979-1983. Indian J. Fish. 1987, 34, 292-305.

9. Abelló, P.; Martín, P. Fishery dynamics of the mantis shrimp Squilla mantis (Crustacea: Stomatopoda) population off the Ebro delta (northwestern Mediterranean). Fish. Res. 1993, 16, 131-145. [CrossRef]

10. Erdmann, M.V.; Caldwell, R.L. Stomatopod crustaceans as bioindicators of marine pollution stress on coral reefs. In Proceedings of the Eighth International Coral Reef Symposium, Panama City, Panama, 24-29 June 1996; Smithsonian Tropical Research Institute: Panama City, Panama, 1997; Volume 2, pp. 1521-1526.

11. Kodama, K.; Shimizu, T.; Yamakawa, T.; Aoki, I. Changes in reproductive patterns in relation to decline in stock abundance of the Japanese mantis shrimp Oratosquilla oratoria in Tokyo Bay. Fish. Sci. 2006, 72, 568-577. [CrossRef]

12. Ng, J.S.S.; Lui, K.K.Y.; Lai, C.-H.; Leung, K.M.Y. Harpiosquilla harpax (Crustacea, Stomatopoda) as a biomonitor of trace metal contamination in benthic sediments in Hong Kong waters. Mar. Pollut. Bull. 2007, 54, 1523-1529. [CrossRef]

13. Antony, P.J.; Dhanya, S.; Lyla, P.S.; Kurup, B.M.; Ajmal Khan, S. Ecological role of stomatopods (mantis shrimps) and potential impacts of trawling in a marine ecosystem of the southeast coast of India. Ecol. Modell. 2010, 221, 2604-2614. [CrossRef]

14. Latreille, P.A. Familles Naturelles Du Règne Animal: Exposées Succinctement et Dans Un Ordre Analytique, Avec Lindication de Leurs Genres; J.-B. Baillière: Paris, France, 1825; p. 283.

15. Schram, F.R. Paleozoic proto-mantis shrimp revisited. J. Paleontol. 2007, 81, 895-916. [CrossRef]

16. Haug, J.T.; Haug, C.; Maas, A.; Kutschera, V.; Waloszek, D. Evolution of mantis shrimps (Stomatopoda, Malacostraca) in the light of new Mesozoic fossils. BMC Evol. Biol. 2010, 10, 290. [CrossRef]

17. Ahyong, S.T.; Harling, C. The phylogeny of the stomatopod Crustacea. Aust. J. Zool. 2000, 48, 607-642. [CrossRef]

18. Van Der Wal, C.; Ahyong, S.T.; Ho, S.Y.W.; Lo, N. The evolutionary history of Stomatopoda (Crustacea: Malacostraca) inferred from molecular data. PeerJ 2017, 5, e3844. [CrossRef]

19. Latreille, P.A. Histoire Naturelle, Générale et Particulière des Crustacés et des Insectes: Ouvrage Faisant Suite aux Owuvres de Leclerc de Buffon, et Partie du Cours Complet d'Histoire Naturelle Rédigé par C. S. Sonnini, Membre de Plusieurs Sociétés Savantes; Dufart: Paris, France, 1802; p. 56.

20. Giesbrecht, W. Stomatopoden. Erster Theil. Fauna Flora Golf. Neapel 1910, 33, 1-239.

21. Manning, R.B. Preliminary account of a new genus and a new family of Stomatopoda. Crustaceana 1967, 13, 238-239. [CrossRef]

22. Manning, R.B. A Monograph of the West African Stomatopod Crustacea; Atlantide Rep. 12; Scandinavian Science Press: Copenhagen, Denmark, 1977; pp. 1-181.

23. Manning, R.B.; Bruce, A.J. Erythrosquilla megalops, a remarkable new stomatopod from the western Indian Ocean. J. Crustacean Biol. 1984, 4, 329-332. [CrossRef]

24. Manning, R.B. Stomatopod Crustacea of Vietnam: The legacy of Raoul Serène. Crustac. Res. 1995, 4, 1-339. [CrossRef]

25. Ahyong, S.T.; Jarman, S.N. Stomatopod interrelationships: Preliminary results based on analysis of three molecular loci. Arthropod Syst. Phylogeny 2009, 67, 1864-8312.

26. Manning, R.B. The superfamilies, families and genera of recent stomatopod Crustacea, with diagnoses of six new families. Proc. Biol. Soc. Wash. 1980, 93, 362-372. 
27. Porter, M.L.; Zhang, Y.; Desai, S.; Caldwell, R.L.; Cronin, T.W. Evolution of anatomical and physiological specialization in the compound eyes of stomatopod crustaceans. J. Exp. Biol. 2010, 213, 3473-3486. [CrossRef]

28. Caldwell, R.L. Stomatopods: The better to see you with my dear. Aust. Nat. Hist. 1991, 23, 696-705.

29. Trevisan, B.; Alcantara, D.M.C.; Machado, D.J.; Marques, F.P.L.; Lahr, D.J.G. Genome skimming is a low-cost and robust strategy to assemble complete mitochondrial genomes from ethanol preserved specimens in biodiversity studies. PeerJ 2019, 7, e7543. [CrossRef]

30. Lin, F.J.; Liu, Y.; Sha, Z.; Tsang, L.M.; Chu, K.H.; Chan, T.Y.; Liu, R.; Cui, Z. Evolution and phylogeny of the mud shrimps (Crustacea: Decapoda) revealed from complete mitochondrial genomes. BMC Genom. 2012, 13, 631. [CrossRef]

31. Cheng, J.; Chan, T.-Y.; Zhang, N.; Sun, S.; Sha, Z.-L. Mitochondrial phylogenomics reveals insights into taxonomy and evolution of Penaeoidea (Crustacea: Decapoda). Zool. Scr. 2018, 47, 582-594. [CrossRef]

32. González-Castellano, I.; Pons, J.; González-Ortegón, E.; Martínez-Lage, A. Mitogenome phylogenetics in the genus Palaemon (Crustacea: Decapoda) sheds light on species crypticism in the rockpool shrimp P. elegans. LoS ONE 2020, 15, e0237037. [CrossRef]

33. Kang, H.-E.; Kim, J.N.; Yoon, T.-H.; Park, K.D.; Park, W.G.; Park, H.; Kim, H.W. Total mitochondrial genome of mantis shrimp, Squilloides leptosquilla (Brooks, 1886) (Crustacea: Stomatopoda: Squillidae) in Korean waters. Mitochondrial DNA A DNA Mapp. Seq. Anal. 2016, 27, 2842-2843. [CrossRef]

34. Zhang, Y.; Bi, Y.; Feng, M. The complete mitochondrial genome of Lophosquillia costata (Malacostraca: Stomatopoda) from China and phylogeny of stomatopods. Mitochondrial DNA Part B 2020, 5, 2495-2497. [CrossRef]

35. Hwang, H.-S.; Shin, J.; Jung, J. Complete mitochondrial genome of the mantis shrimp Taku spinosocarinatus (Fukuda, 1909) (Stomatopoda: Gonodactyloidea: Takuidae) in South Korea. Mitochondrial DNA Part B 2020, 5, 3609-3610. [CrossRef]

36. Yang, M.; Liu, H.; Wang, R.; Tan, W. The complete mitochondrial genome of purple spot mantis shrimp Gonodactylus smithii (Pocock, 1893). Mitochondrial DNA Part B 2021, 6, 2028-2030. [CrossRef]

37. Rafinesque, C.S. Analyse de la Nature, ou Tableau de l'Univers et des Corps Organisés; Self-Published: Palermo, Italy, 1815.

38. Manning, R.B. Stomatopod Crustacea Collected by the Yale Seychelles Expedition, 1957-1958; Yale Peabody Museum of Natural History: Edinburgh, UK, 1962; Volume 68.

39. Paul'son, O. Studies on Crustacea of the Red Sea with Notes Regarding Other Seas. Part I. Podophthalmata and Edriophthalmata (Cumacea); S.V. Kul'zhenko: Kiev, Ukraine, 1875; pp. 1-144. (In Russian)

40. Ahyong, S.T. Revision of the Australian stomatopod Crustacea. Rec. Aust. Mus. 2001, 26, 1-326. [CrossRef]

41. Folmer, O.; Black, M.; Hoeh, W.; Lutz, R.; Vrijenhoek, R. DNA primers for amplification of mitochondrial cytochrome c oxidase subunit I from diverse metazoan invertebrates. Mol. Mar. Biol. Biotechnol. 1994, 3, 294-299.

42. Shen, W.; Le, S.; Li, Y.; Hu, F. SeqKit: A Cross-Platform and Ultrafast Toolkit for FASTA/Q File Manipulation. PLoS ONE 2016, 11, e0163962. [CrossRef] [PubMed]

43. Bolger, A.M.; Lohse, M.; Usadel, B. Trimmomatic: A flexible trimmer for Illumina sequence data. Bioinformatics 2014, 30, 2114-2120. [CrossRef] [PubMed]

44. Allio, R.; Schomaker-Bastos, A.; Romiguier, J.; Prosdocimi, F.; Nabholz, B.; Delsuc, F. MitoFinder: Efficient automated large-scale extraction of mitogenomic data in target enrichment phylogenomics. Mol. Ecol. Resour. 2020, 20, 892-905. [CrossRef] [PubMed]

45. Li, D.; Luo, R.; Liu, C.-M.; Leung, C.-M.; Ting, H.-F.; Sadakane, K.; Yamashita, H.; Lam, T.-W. MEGAHIT v1.0: A fast and scalable metagenome assembler driven by advanced methodologies and community practices. Methods 2016, 102, 3-11. [CrossRef]

46. Laslett, D.; Canbäck, B. ARWEN: A program to detect tRNA genes in metazoan mitochondrial nucleotide sequences. Bioinformatics 2008, 24, 172-175. [CrossRef]

47. Bernt, M.; Donath, A.; Jühling, F.; Externbrink, F.; Florentz, C.; Fritzsch, G.; Pütz, J.; Middendorf, M.; Stadler, P.F. MITOS: Improved de novo metazoan mitochondrial genome annotation. Mol. Phylogenet. Evol. 2013, 69, 313-319. [CrossRef]

48. Kearse, M.; Moir, R.; Wilson, A.; Stones-Havas, S.; Cheung, M.; Sturrock, S.; Buxton, S.; Cooper, A.; Markowitz, S.; Duran, C.; et al. Geneious Basic: An integrated and extendable desktop software platform for the organization and analysis of sequence data. Bioinformatics 2012, 28, 1647-1649. [CrossRef]

49. Stephenson, W. A comparison of Australasian and American Specimens of Hemisquilla ensigera (Owen, 1832) (Crustacea: Stomatopoda). Proc. U. S. Natl. Mus. 1967, 120, 1-18. [CrossRef]

50. Bigelow, R.P. Preliminary notes on the Stomatopoda of the Albatross collections and on other specimens in the National Museum. Johns Hopkins Univ. Circ. 1893, 12, 100-102.

51. Hansen, J.H. Isopoden, Cumaceen Und Stomatopoden Der Plankton-Expedition. Ergeb. Plankton-Exped. Der Humboldt-Stift. 1895, 2, 1-105.

52. Manning, R.B. Stomatopod Crustacea of the western Atlantic. Stud. Trop. Oceanogr. 1969, 8, 1-380.

53. Pocock, R.I. Report upon the stomatopod crustaceans obtained by P. W. Bassett-Smith, Esq., Surgeon, R. N., during the cruise, in the Australian and China seas, of H.M.S. "Penguin," Commander W. U. Moore. Ann. Mag. Nat. Hist. 1893, 11, 473-479. [CrossRef]

54. Fabricius, J.C. Species Insectorum Exhibentes Eorum Differentias Specificas, Synonyma Auctorum, Loca Natalia, Metamorphosin Adiectis, Observationibus, Descriptionibus; C.E. Bohnii: Hamburg, Germany; Kiel, Germany, 1781; Volume 1, pp. 1-552.

55. Manning, R.B. Notes on some species of the Falcatus group of Gonodactylus (Crustacea: Stomatopoda: Gonodactylidae). Smithson. Contrib. Zool. 1978, 258, 1-15. [CrossRef]

56. Fukuda, T. The Stomatopoda of Japan. Dobutsugaku Zasshi 1909, 21, 54-62. 
57. Fabricius, J.C. Mantissa Insectorum, Sistens Eorum Species Nuper Detectas, Adjectis Characteribus Genericis, Differentiis Specificis, Emendationibus Observationibus; C. G. Proft: Copenhagen, Germany, 1787; Volume 1, p. 348.

58. Hwang, H.-S.; Ahyong, S.T.; Kim, W. A new species of Chorisquilla Manning, 1969 (Stomatopoda: Protosquillidae) from Korea and Japan with redescription of C. mehtae Erdmann Manning, 1998. Zootaxa 2018, 4483, 365-374. [CrossRef]

59. De Haan, W. Crustacea. In Von Siebold, P.F., Fauna Japonica sive Descriptio Animalium, quae in Itinere per Japoniam, Jussu et Auspiciis Superiorum, qui Summum in India Batava Imperium Tenent, Suspecto, Annis 1823-1830 Collegit, Notis; Observationibus et Adumbrationibus Illustravit: Leiden, The Netherlands, 1844; pp. 1-243.

60. Linnaeus, C. Systema Naturae per Regna Tria Naturae, Secundum Classes, Ordines, Genera, Species, cum Characteribus, Differentiis, Synonymis, Locis; Laurentius Salvius Holmiae: Stockholm, Sweden, 1758; Volume 1, p. 824.

61. Say, T. An account of the Crustacea of the United States. J. Acad. Nat. Sci. Phila. 1818, 1, 445-458.

62. Bigelow, R.P. Preliminary notes on some new species of Squilla. Johns Hopkins Univ. Circle 1891, 10, 93-94.

63. Brooks, W.K. Report on the Stomatopoda collected by HMS Challenger during the years 1873-76. Rep. Sci. Results Voyag. HMS Chall. Zool. 1886, 16, 1-115.

64. Wood-Mason, J. Figures and Descriptions of Nine Species of Squillidae from the Collection in the Indian Museum; Indian Museum: Calcutta, India, 1895; pp. 1-11.

65. Fabricius, J.C. Entomologia Systematica Emendata et Aucta. Secundum Classes, Ordines, Genera, Species Adjectis Synonimis, Locis, Observationibus, Descriptionibus; Christ. Gottl. Proft: Copenhagen, Denmark, 1793; Volume 2, pp. 1-519.

66. Holthuis, L.B. Stomatopod Crustacea of Suriname. Stud. Fauna Suriname Other Guyanas 1959, 3, $173-191$.

67. Hansen, H.J. The genera and species of the order Euphausiacea, with account of remarkable variation. Bull. L'institut Océanographique Monaco 1911, 210, 1-54.

68. Nakazawa, K. Notes on Japanese Schizopoda. Annot. Zool. Jpn. 1910, 7, 247-261.

69. Schioedte, J.C.; Meinert, F.W. Symbolae ad Monographiam Cymothoarum Isopodum Familiae 4. Cymothoidae. Trib. II. Cymothoinae. Trib. III. Livonecinae. Nat. Tidsskr. 1884, 3, 221-454.

70. Schwentner, M.; Richter, S.; Rogers, D.C.; Giribet, G. Tetraconatan phylogeny with special focus on Malacostraca and Branchiopoda: Highlighting the strength of taxon-specific matrices in phylogenomics. Proc. Biol. Sci. 2018, 285, 20181524. [CrossRef]

71. Lozano-Fernandez, J.; Giacomelli, M.; Fleming, J.F.; Chen, A.; Vinther, J.; Thomsen, P.F.; Glenner, H.; Palero, F.; Legg, D.A.; Iliffe, T.M.; et al. Pancrustacean Evolution Illuminated by Taxon-Rich Genomic-Scale Data Sets with an Expanded Remipede Sampling. Genome Biol. Evol. 2019, 11, 2055-2070. [CrossRef]

72. Castresana, J. Selection of conserved blocks from multiple alignments for their use in phylogenetic analysis. Mol. Biol. Evol. 2000 17, 540-552. [CrossRef]

73. Katoh, K.; Standley, D.M. MAFFT Multiple Sequence Alignment Software Version 7: Improvements in Performance and Usability. Mol. Biol. Evol. 2013, 30, 772-780. [CrossRef]

74. Edler, D.; Klein, J.; Antonelli, A.; Silvestro, D. raxmlGUI 2.0: A graphical interface and toolkit for phylogenetic analyses using RAxML. Methods Ecol. Evol. 2021, 12, 373-377. [CrossRef]

75. Kozlov, A.M.; Darriba, D.; Flouri, T.; Morel, B.; Stamatakis, A. RAxML-NG: A fast, scalable and user-friendly tool for maximum likelihood phylogenetic inference. Bioinformatics 2019, 35, 4453-4455. [CrossRef]

76. Darriba, D.; Posada, D.; Kozlov, A.M.; Stamatakis, A.; Morel, B.; Flouri, T. ModelTest-NG: A New and Scalable Tool for the Selection of DNA and Protein Evolutionary Models. Mol. Biol. Evol. 2020, 37, 291-294. [CrossRef]

77. Maddison, W.P.; Maddison, D.R. Mesquite: A Modular System for Evolutionary Analysis. Version 3.61. 2019. Available online: http:/ / www.mesquiteproject.org (accessed on 30 November 2021).

78. Swofford, D.L. PAUP *. Phylogenetic Analysis Using Parsimony ( ${ }^{*}$ and Other Methods); Version 4; Sinauer Associates: Sunderland, MA, USA, 2003.

79. Ronquist, F.; Teslenko, M.; van der Mark, P.; Ayres, D.L.; Darling, A.; Höhna, S.; Larget, B.; Liu, L.; Suchard, M.A.; Huelsenbeck, J.P. MrBayes 3.2: Efficient Bayesian Phylogenetic Inference and Model Choice across a Large Model Space. Syst. Biol. 2012, 61, 539-542. [CrossRef]

80. Rambaut, A.; Drummond, A.J.; Xie, D.; Baele, G.; Suchard, M.A. Posterior summarisation in Bayesian phylogenetics using Tracer 1.7. Syst. Biol. 2018, 67, 901-904. [CrossRef] [PubMed]

81. Shimodaira, H. An Approximately Unbiased test of phylogenetic tree selection. Syst. Biol. 2002, 51, 492-508. [CrossRef] [PubMed]

82. Nguyen, L.-T.; Schmidt, H.A.; von Haeseler, A.; Minh, B.Q. IQ-TREE: A fast and effective stochastic algorithm for estimating maximum-likelihood phylogenies. Mol. Biol. Evol. 2015, 32, 268-274. [CrossRef] [PubMed]

83. Chernomor, O.; von Haeseler, A.; Minh, B.Q. Terrace aware data structure for phylogenomic inference from supermatrices. Syst. Biol. 2016, 65, 997-1008. [CrossRef]

84. Schram, F.R.; Ahyong, S.T.; Patek, S.N.; Green, P.A.; Rosario, M.V.; Bok, M.J.; Cronin, T.W.; Vetter, K.S.M.; Caldwell, R.L.; Scholtz, G.; et al. Subclass Hoplocarida Calman, 1904: Order Stomatopoda Latreille, 18171. In Treatise on Zoology-Anatomy, Taxonomy, Biology. The Crustacea, Volume 4 Part A; Brill: Leiden, The Netherlands, 2013; pp. 179-355.

85. Barber, P.H.; Erdmann, M.V. Molecular systematics of the Gonodactylidae (Stomatopoda) using mitochondrial cytochrome oxidase C (Subunit 1) DNA sequence data. J. Crustacean Biol. 2000, 20, 20-36. [CrossRef]

86. Dana, J. United States Exploring Expedition. During the Year 1838, 1839, 1840, 1841, 1842; C. Sherman: Philadelphia, PA, USA, 1852; Volume 13, pp. 615-623. 
87. Caldwell, R.L.; Dingle, H. Stomatopods. Sci. Am. 1976, 234, 80-89. [CrossRef]

88. DeVries, M.S.; Stock, B.C.; Christy, J.H.; Goldsmith, G.R.; Dawson, T.E. Specialized morphology corresponds to a generalist diet: Linking form and function in smashing mantis shrimp crustaceans. Oecologia 2016, 182, 429-442. [CrossRef] [PubMed]

89. DeVries, M.S. The role of feeding morphology and competition in governing the diet breadth of sympatric stomatopod crustaceans. Biol. Lett. 2017, 13, 20170055. [CrossRef]

90. Boore, J.L.; Lavrov, D.V.; Brown, W.M. Gene translocation links insects and crustaceans. Nature 1998, 392, 667-668. [CrossRef]

91. Kilpert, F.; Podsiadlowski, L. The complete mitochondrial genome of the common sea slater, Ligia oceanica (Crustacea, Isopoda) bears a novel gene order and unusual control region features. BMC Genom. 2006, 7, 241. [CrossRef] [PubMed] 